\title{
O consumo no contexto da experiência urbana: reflexões sobre os telefones celulares*
}

\author{
Sandra Rúbia da Silva
}

Universidade Federal de Santa Catarina

\section{Resumo}

Se é verdade que por muito tempo Simmel foi pouco ou mal lido, seu pensamento é atualmente cada vez mais valorizado para a teorização da centralidade do indivíduo no discurso da modernidade, assim como na sua relação com o dinheiro e, por conseqüência, com o consumo e as formas de sociabilidade a ele associadas. $\mathrm{O}$ artigo tem o objetivo de sublinhar a atualidade dos insights simmelianos para a reflexão em torno de um fenômeno que atravessa a cultura contemporânea de forma inapelável: a disseminação do uso de telefones celulares, que fazem parte do dia-a-dia de cada um de nós. Nesse sentido, a partir da abordagem do consumo como comunicação e da experiência urbana em Simmel, busca-se explorar o papel dos telefones celulares na construção de identidades e na apresentação pessoal dos agentes sociais.

Palavras-chave: Consumo; moda; telefones celulares; identidades.

\begin{abstract}
It may be true that Georg Simmel has either been poorly or insufficiently read for too long. However, his works are nowadays being increasingly taken into account for the theorization of the centrality of the individual in the discourse of modernity, as well as his/her relationship to money and, as a consequence, forms of sociability associated to it. This article aims at highlighting the relevance of Simmel's insights for the reflection about a phenomenon which is undeniably present in contemporary life: the dissemination of the use of cell phones, which are part of almost everyone's everyday life. Therefore,

Consumption as communication in the context of urban experience some notes about cell phones ${ }^{1}$ Doutoranda vinculada ao NAVI/GAUM/UFSC - Núcleo de Antropologia Visual, Urbana e Marítima do Programa de Pós-Graduação em Antropologia Social da Universidade Federal de Santa Catarina. (sandra_rubia@hotmail.com).
\end{abstract}




\title{
HÜMANAS
}

by associating Simmel's theories about consumption as a way of communication in the context of urban experience with ethnographic data provided by recent research carried out in Brazil and other countries, I seek to explore the role of cell phones in the construction of identities and in the forms of social agents' self-presentation.

Keywords: Consumption; fashion; cell phones; identities.

\begin{abstract}
$\mathrm{A}$ obra de Simmel é produto de seu tempo. Nascido em 1858 e falecido em 1918, Simmel vive todo o momento de profundas mudanças históricas e sociais pelo qual passava a Alemanha da época, com a crescente industrialização, migração das populações do campo para as cidades e conseqüente formação dos primeiros núcleos urbanos a serem chamados propriamente de metrópoles. É a partir desse contexto que Simmel, como cientista social, interessa-se pelo fenômeno da vida do indivíduo na grande metrópole, assim como pelo papel do dinheiro nessa relação, tema de seu livro A filosofia do dinheiro, publicado originalmente em 1900. Neste texto, como também no seminal $A$ metrópole e a vida mental, publicado pela primeira vez em 1902, Simmel lança as bases filosóficas e sociológicas para a compreensão das interações entre indivíduo e metrópole, a partir de suas características.

A abordagem microssociológica de Simmel encontrou especial ressonância nos pensadores da Escola de Chicago, que adotaram suas idéias para constituir o campo da Antropologia Urbana. Se é bem verdade que por muito tempo Simmel foi pouco ou mal lido, ou ainda mesmo não citado exceção feita à Escola de Chicago - seu pensamento é agora retomado e sua influência crescente para pensar questões que vão da crescente centralidade do indivíduo no discurso da modernidade, sua relação com o dinheiro - e, por conseqüência, o consumo - à chamada "ciborguização"2 das grandes metrópoles: ou seja, a cada vez maior interrelação entre indivíduos e novas tecnologias de comunicação e informação no ambiente urbano.

Em $A$ metrópole e a vida mental, Simmel advoga em favor da idéia de que o indivíduo no seio da vida moderna deseja preservar, antes de mais nada,

\footnotetext{
${ }^{2}$ Conceito trabalhado pelo pesquisador André Lemos, da Universidade Federal da Bahia, em seu projeto de pesquisa "Cibercidades". Um desenvolvimento do conceito pode ser lido em Lemos, André. Cibercultura e mobilidade. A era da conexão. Anais do XXVIII Congresso Brasileiro de Ciências da Comunicação, 2005.
} 
sua autonomia e o individualismo de sua existência, os quais são constantemente ameaçados devido à característica esmagadora das forças sociais que sobre ele atuam. O objeto de preocupação de Simmel é justamente a investigação e a discussão de como a personalidade do indivíduo se acomoda, ou se ajusta, à tais forças externas que a metrópole cria.

Como entender, então, a vida psíquica metropolitana? Para Simmel, a base psicológica do tipo metropolitano de individualismo consiste na intensificação dos estímulos nervosos. Como resultado, o homem metropolitano desenvolve um "órgão" que o protege - ou melhor seria dizer que o capacita? - a lidar com a vida na metrópole, caracterizada pela valorização do dinheiro e da ambição: é o domínio do intelecto. Trata-se de desenvolver mecanismos onde o indivíduo pensa e reage com a cabeça, por oposição à vida no campo, caracterizada por relacionamentos profundos e onde o indivíduo reage com o coração. Na metrópole, a superficialidade das relações e a impessoalidade das trocas fundam-se na racionalidade. Trabalha-se com o sujeito como um número: metáfora que diz muito do pensamento de Simmel sobre o anonimato e a solidão da vida dos indivíduos na grande metrópole, rodeados que estão pelas multidões que caminham incessantemente. Na comparação da vida dos indivíduos no começo do século XX e no começo do século XXI, podemos dizer que, ainda mais do que tratado "como um número" o indivíduo em si "torna-se" vários números, simbolizados, entre outros exemplos, pelas inúmeras senhas indispensáveis ao acesso das benesses da vida moderna.

Portanto, a metrópole é o lugar da economia monetária e do domínio do intelecto, lugar de trocas impessoais regidas pelo poder do dinheiro, "denominador comum de todos os valores" 1979; p. 19). O indivíduo, em Simmel, é portanto equiparado ao dinheiro, que permeia todas as relações sociais. $\mathrm{O}$ mecanismo de defesa - ou "fenômeno psíquico", nas palavras do autor - desenvolvido pelo domínio do intelecto é chamado por Simmel de atitude blasé. Tal atitude caracteriza-se por uma atitude de reserva, ou mesmo de indiferença, de um metropolitano para com outro, assim como pelos eventos que ocorrem na metrópole. O embotamento do poder de discriminar - ou seja, trata-se aqui de pensar em uma indiferença às diferenças - produzido pelo excesso de estímulos, é outra forma de caracterizar o blasé. Embora muitos autores entendam Simmel como crítico do blasé, uma leitura mais cuidadosa partece dizer o contrário: Simmel encara o blasé, conforme mencionado anteriormente, antes como mecanismo de defesa necessário à vida na metrópole. 


\section{HüMANAs}

A argumentação de Simmel a respeito da construção do indivíduo em em sua obra, e especialmente em $A$ metrópole e a vida mental, apóia-se em um tripé, portanto. Na base, está a concepção durkheimiana de intelecto. A emergência da vida intelectual, tanto para Durkheim quanto para Simmel, está diretamente ligada à emergência do intelectualismo na vida moderna, ou seja, o desenvolvimento do indivíduo se dá pelo cultivo de uma vida interior, do exercício do livre-arbítrio, da independência e da autonomia. Segundo Simmel, é a metrópole que fornece a arena para que os indivíduos exerçam os valores da autonomia, da liberdade e da criatividade, tão caros ao individualismo moderno. Os outros dois pontos de apoio do tripé são justamente a noção de que a vida do indivíduo na metrópole é mediada pelo dinheiro e a característica blasé da atitude dos cidadãos. A característica hedonista do individualismo moderno é explorada por Simmel em seu argumento de que a metrópole é o lugar da liberdade por excelência - "confere ao indivíduo uma qualidade e quantidade de liberdade pessoal que não tem qualquer analogia sob outras condições" $(1979 ;$ p. 18) - lugar de experiências mais intensas e variadas que o indivíduo não poderia ter no campo. Entretanto, podemos dizer que essa liberdade e esse gozo hedonístico são de certa forma paradoxais. Os mesmos estímulos nervosos que possibilitam diferentes experiências podem tornar o indivíduo blasé a ponto de embotar seus sentimentos e seu discernimento.

Simmel fala de um deslocamento ou descentramento do indivíduo, causado por estímulos, conteúdos, interesses e empregos de tempo e consciência que lhe vem de todos os lados. Tais elementos "tendem a desalojar as genuínas colorações e as características de incomparabilidade pessoais. Isso resulta em que o indivíduo apele para o extremo no que se refere à exclusividade e particularização, para preservar sua essência mais pessoal [...] para permanecer perceptível até para si próprio" (1979; p. 24).

Se nas sociedades ditas primitivas a ligação entre os indivíduos se dá por parentesco, sangue, ou seja, pelo vínculo comunitário, na metrópole Simmel afirma que são as trocas monetárias e, assim podemos dizer, o consumo, que ligam os metropolitanos através do desejo de individualização por uma diferença que $o$ autor chama de qualitativa. A afirmação da personalidade na metrópole, assim sendo, procura atrair a atenção do círculo social através da diferenciação. Embora neste texto Simmel não seja completamente específico a esse respeito, desenvolverá em outro lugar o argumento de que o consumo de bens é uma maneira de atingir tal diferenciação. 
Nesse registro, é fundamental considerar que no mundo moderno, cada vez mais, o indivíduo se subordina ao papel de consumidor. Nesse sentido, o pensamento de Simmel é, uma vez mais, precursor. Simmel destaca que os ideais de liberalismo do século XVIII, assim como as idéias de Goethe e do romantismo no século XIX - aliados à divisão econômica do trabalho - conduzem à liberação dos indivíduos de vínculos históricos (leia-se vínculos préiluministas) e ao seu desejo de distinguirem-se uns dos outros. A revolução do consumo, desta forma, parece ter um papel fundamental na formulação do conceito ocidental de pessoa (MCCRACKEN, 2003). Nesse sentido, Campbell (2001) relaciona o aparecimento do consumismo moderno com a ética romântica que valoriza o indivíduo e estimula a busca do prazer emocional. O autor denuncia a inaptidão do utilitarismo para o estudo do consumo e defende que a origem das necessidades reside em um modelo hedonista da ação humana - o prazer, e não a satisfação de uma necessidade, é o objetivo do consumo. Para Simmel, é a busca desenfreada do prazer que torna o indivíduo blasé. Nas palavras de Simmel: "Uma vida em perseguição desregrada ao prazer torna uma pessoa blasé porque agita os nervos até seu ponto de mais forte reatividade por um tempo tão longo que eles finalmente cessam de reagir." $(1979$, p.16). Não pode ser encarada como atitude blasé, nesse sentido, a postura do internauta que displicentemente fecha várias janelas de anúncios publicitários para acessar o conteúdo de sua página no Orkut? Ou que troca de aparelho celular constantemente, a cada novo lançamento?

É justamente em outro texto seminal, sobre a filosofia da moda ${ }^{3}$, que Simmel (2002 [1904]) irá avançar nos argumentos anteriores em torno da necessidade de diferenciação do indivíduo na metrópole, lançando idéias sobre a moda como mecanismo de diferenciação social, as quais continuam atuais até hoje. É nesse sentido que Simmel (2002) considera a moda um instrumento ou forma de comunicação que indica regimes de status e de poder a respeito dos indivíduos.

Como a moda se torna tão importante no seio da modernidade? Para Simmel (antecipando, poderíamos dizer, os teóricos pós-modernos do consumo, como Featherstone e Baudrillard) entre as causas está a perda de força na crença em grandes convicções, duradouras e inquestionáveis.

\footnotetext{
${ }^{3}$ Vale enfatizar que este texto circula bastante entre os teóricos do consumo no universo acadêmico de língua inglesa. O texto, originalmente publicado em 1904, é publicado em língua inglesa sob o título "Fashion" em 1957, na revista International Quarterly. Em espanhol, recebeu o título de Filosofia de la moda.
} 


\section{Hümanas}

Esse rompimento com o passado e com o futuro traz uma consciência aguda do presente, com a conseqüente ênfase na mudança e em tudo o que é variável. A moda indica, assim, a relação específica da modernidade com o tempo: é um tempo impaciente, que indica não apenas a ânsia de rápida mutação dos conteúdos qualitativos da vida, mas de fato a crescente intensidade dos ciclos temporais.

A moda, para Simmel, estabelece um equilíbrio muito original entre o impulso social e o impulso indivịdualizador, já que funciona através de uma contradição interna: une e diferencia ao mesmo tempo. Segundo Simmel, isso significa dizer que existe no indivíduo um propensão psíquica à imitação que se traduz em um impulso socializador, o leva a querer fazer parte de um grupo no qual se reconheça e com o qual se identifique. Porém, ao mesmo tempo, a necessidade de diferenciação persiste. Amoda, revela Simmel, só se forma a partir de duas tendências sociais: justamente a concentração dos indivíduos em um grupo e a separação entre este e os demais. Portanto, Simmel identifica que a moda surge na modemidade, fundamentalmente, para cumprir uma função de diferenciação entre membros de distintas classes sociais. Esse mecanismo é intensificado pelo capitalismo: Simmel assume que as classes inferiores aspiram ao status mais elevado. Entretanto, evidentemente, o mesmo não ocorre com as classes dominantes. A moda traz em sua essência, portanto, um poder diferenciador: é da essência da moda que "só participe dela uma parte da sociedade, enquanto o resto se acha sempre a caminho dela, sem alcançá-la nunca." (SIMMEL, 2002; p. 369). Nesse sentido, o principal argumento de Simmel é o de que "sempre as modas são modas de classe, já que as modas da classe social superior se diferenciam da inferior e são abandonadas no momento em que esta começa a apropriar-se daquelas." (SIMMEL, 2002; p. 363).

Definidas os principais argumentos simmelianos em torno do individualismo moderno e da experiência urbana, assim como da abordagem do consumo como comunicação, passaremos agora a explorar a atualidade de seu pensamento no estudo do papel dos telefones celulares na construção de identidades e no surgimento de novas formas de sociabilidade no espaço urbano. Apresentaremos dados etnográficos atualizados de pesquisas recentes que dão conta de novas formas de sociabilidade associadas ao uso de celulares, bem como de seu papel na construção e afirmação de identidades. Na seção seguinte, apresentamos os dados de nosso próprio trabalho de campo, estabelecendo relações entre a moda e os telefones celulares na construção de identidades sociais, a partir da percepção de camadas médias e populares. 
O consumo no contexto da experiência urbana: reflexões sobre os telefones celulares Sandra Rúbia da Silva

O trabalho da antropóloga Genevieve Bell (2004) também contribui para a discussão sobre as maneiras pelas quais o celular funciona como demarcador de identidades sociais. A autora (2004) constata que os celulares parecem ter se inserido de maneira definitiva no tecido cultural das sociedades ao redor do mundo. Bell é responsável por um projeto etnográfico comparativo com duração de dois anos, financiado pela Intel, cujo objetivo é compreender melhor a relação das camadas urbanas médias da Ásia com a tecnologia: como estas a utilizam e a percebem no seu dia-a-dia. Tomando como base seu trabalho etnográfico na Ásia, Bell argumenta que, muito mais do que mera tecnologia de comunicação, os celulares também tornaram-se marcadores simbólicos das identidades na contemporaneidade. Trago aqui duas evidências etnográficas apontadas por Bell: em junho de 2002, as bancas de revista na Malásia vendiam a última edição da revista Mobile Stuff, destinada à crescente população malaia assinante de telefonia celular. $\mathrm{Na}$ capa, dois jovens homens malaios vestidos com roupas que mais lembram os bairros de Los Angeles do que os subúrbios da Malásia seguram seus celulares agressivamente para a câmera. Acima da imagem, a inscrição: "Homens de verdade usam SMS ${ }^{4}$ ". Seis meses mais tarde, outdoors em Shangai mostravam a imagem de uma jovem vestida com tiras de couro preto; posicionado embaixo de uma das tiras estava seu telefone celular.

Em From kinship to link-up, artigo recentemente publicado na revista Current Anthropology, os pesquisadores Daniel Miller e Heather Horst (2005) dão conta de pesquisa concluída em campo etnográfico localizado na Jamaica. Tomando como base a lista de números de telefone salvos no $s$ aparelhos celulares de seus informantes, argumentam que os jamaicanos de camadas populares utilizam o telefone celular para estabelecer redes de relacionamentos. Essa prática é chamada de link-up (numa tradução livre, "ligar-se"). A prática do link-up guarda muitas das características atribuídas em estudos anteriores aos sistemas de parentesco e genealogias jamaicanos. Entretanto, os novos achados de pesquisa sugerem que o parentesco meramente exemplifica um padrão que pode ser encontrado em grande número de estratégias de formação de redes de relacionamento jamaicanas. Tais estratégias incluem a criação de comunidades religiosas e espirituais, a busca por parceiros sexuais, e elaboração de estratégias de sobrevivência adotadas por famílias de baixa renda. $\mathrm{O}$ link-up também possui grande peso na rápida adoção do uso de telefones celulares na Jamaica,

\footnotetext{
${ }^{4}$ Short Message Service, serviço de telefonia móvel que no Brasil também é conhecido por "torpedo".
} 
influenciando diretamente os padrões de uso adotados pelas camadas populares. Assim, fica evidenciada a importância de os pesquisadores compreenderem os padrões locais de incorporação dos telefones celulares, assim como as formas locais de formação de redes de relacionamento tornadas possíveis pelo advento das novas tecnologias de informação e comunicação (MILLER \& HORST, 2005).

Como vimos, a pesquisa sobre telefones celulares é bastante recente, sendo desenvolvida principalmente nos Estados Unidos e na Europa. No caso brasileiro, um dos poucos trabalhos existentes é o de Francisca Silva do Nascimento, intitulado Os últimos serão dos primeiros. Trata-se de uma análise sociológica dos telefones celulares, na qual a autora (2004) realiza uma análise comparativa entre dois grupos distintos de adolescentes: estudantes de classe média alta de de um colégio particular e jovens de renda mais baixa: os "pagodeiros". Para ambos os grupos, o telefone celular atua claramente como mecanismo de diferenciação social. Ambos os grupos o valorizam em seu aspecto simbólico, já que ter um celular é requisito para integrar o grupo; além disso, ambos o percebem como mecanismo que não só integra os membros do grupo entre si mas também os conecta ao estilo de consumo tecnológico característico da modernidade. Entretanto, as diferenças entre os dois grupos são, obviamente, pautadas pelo poder aquisitivo: enquanto os "pagodeiros" compram aparelhos celulares de segunda mão, pré-pagos, e economizam para poder recarregar os créditos de três em três meses, os adolescentes abastados falam o quanto quiserem pois a conta é paga por seus pais. Em contraste, os celulares dos "pagodeiros" são muitas vezes velhos, com teclas que não funcionam ou mesmo funções não mais disponiveis. Entretanto, para eles, ainda que com um aparelho ultrapassado, ter um celular significa estar integrado à dinâmica da vida moderna (Nascimento, 2004). Já os adolescentes do colégio particular utilizam igualmente a função instrumental do celular para fazer e receber ligações; porém, suas formas de consumo transcendem o valor utilitário na medida em que procuram trocar de celular constantemente, a cada novo lançamento. Ter um "celular de pagodeiro", para os adolescentes pesquisados por Nascimento em Fortaleza, é sinônimo de ter um "celular ultrapassado". A função instrumental não é o mais importante no ato da compra, mas sim elementos como o design".

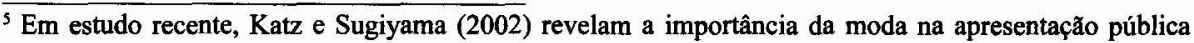
da tecnologia, imaginário esse construído principalmente pela publicidade.
} 
Para Nascimento, tais constatações confirmam a hipótese de que o telefone celular, na medida em que faz parte de uma categoria de objetos que servem para distinguir, atua como marca de diferenciação dos grupos estudados. No argumento de Simmel, a moda é em si arbitrária, revelando sua perfeita indiferença ante as normas práticas e racionais da vida. Suas motivações são de caráter tipicamente social. (SIMMEL, 2002).

\section{Relações entre identidades sociais, moda e telefones celulares a par- tir da percepção de camadas médias e populares}

As análises a seguir, inspiradas nas teorias de Simmel sobre a moda, representam os resultados preliminares da primeira fase de meu trabalho de campo, que faz parte de pesquisa em andamento para a tese de doutorado que atualmente desenvolvo no âmbito da linha de pesquisa em Comunicação e Cultura do Programa de Pós-Graduação em Antropologia Social da Universidade Federal de Santa Catarina (UFSC) ${ }^{6}$.

De seu desenvolvimento inicial voltado para uso por profissionais do mundo dos negócios, os telefones celulares rapidamente passaram a desempenhar um papel como objeto de consumo ligado à negociação de identidades e da experiência social, principalmente no caso de crianças e adolescentes - embora, de forma alguma, restrito à eles. Nesse sentido, Ito (2003) descreve como os celulares foram apropriados pelas adolescentes japonesas como tecnologia de comunicação pessoal, criando uma cultura juvenil do celular no Japão que subseqüentemente influenciou o design e o desenvolvimento dos novos aparelhos.

Aqui no Brasil, a enorme variedade de aparelhos disponíveis, a multiplicidade de acessórios e a disseminação de seu uso entre todas as camadas sociais sinalizam seu impacto sobre as produções identitárias, indicando que o celular já há muito transcendeu uma mera função utilitária de apenas fazer ligações.

\footnotetext{
${ }^{6}$ Durante os meses de janeiro a maio de 2007 , foram feitas observações em locais públicos e na Internet, no site de relacionamentos Orkut (www.orkut.com). Existem mais de mil comunidades sobre celulares no Orkut, conforme atesta o mecanismo de busca por comunidades no site quando são usadas as palavras "celular" ou "celulares". Entretanto, não foi possível determinar o número exato. Além disso, foram realizadas sete entrevistas em profundidade com indivíduos de camadas médias e populares das cidades de Blumenau e Florianópolis/SC, na faixa etária entre vinte e quarenta anos de idade. Embora utilizando um roteiro de seis itens, procurei ter como objetivo uma entrevista o mais próximo possível de um bate-papo informal. As entrevistas foram realizadas nas residências dos informantes e, em três casos, em seus locais de estudo. As transcrições refletem a espontaneidade da conversa e minhas observações, complementos e intervenções à fala dos informantes estão destacadas entre colchetes. Estão igualmente destacados os trechos dos depoimentos que, no meu entendimento, reforçam a argumentação proposta.
} 


\section{HüMANAS}

Tornou-se um acessório de moda, a ser personalizado de acordo com o dono ou a dona - muitas vezes funcionando como uma extensão da pessoa - e constituindo um importante elemento da apresentação pessoal dos indivíduos.

O depoimento de Paula ${ }^{7}$, na faixa etária dos trinta, publicitária e professora universitária, revela sua opinião sobre a questão de as pessoas comprarem telefones celulares pensando nos mesmos como um acessório de moda. Igualmente, Paula acredita que o celular possa dizer muito sobre a personalidade da pessoa, sobre quem ela é:

Olha, eu acredito que isso seja uma realidade hoje em dia. É... com o contato que a gente tem com amigos, com colegas, a gente acaba percebendo que dependendo do estilo da pessoa, $o$ celular ele combina. Se é uma pessoa mais moderna, que gosta de inovações, ele pega o celular com novas tecnologias, as mulheres gostam de celular colorido... Eu por exemplo tenho um celular que a capinha é toda cheia de brilho, porque eu adoro brilho... As minhas colegas também, a gente aproveita já a funcionalidade da câmera pra utilizar, como complemento do celular. Eu acho que ele realmente acabou sendo, se tornando um acessório de moda pra gente, pros adolescentes, como um todo. Acredito que [o celular] diga muito [sobre quem a pessoa é] porque é um acessório que tá com a gente no dia-a-dia né, então ele acaba se tornando um complemento da nossa roupa, e você dependendo da tua profissão, tal, acaba se tornando uma agenda, computador... e até os próprios acessórios acabam dizendo respeito a isso. Olhando para o celular da pessoa a gente acaba realmente vendo um pouquinho dela. Eu por exemplo adoro brilho; gostei sempre de brilho no brinco, no anel, o meu celular não podia deixar de ter um brilho, né... (...) É, assim como a vestimenta, como o perfume, como o óculos, acessórios que você tá usando...

\footnotetext{
7 Todos os nomes dos informantes são fictícios.
} 
O consumo no contexto da experiência urbana: reflexões sobre os telefones celulares

Sandra Rúbia da Silva

Se Paula enfeita o seu aparelho celular com capinha de brilho, da mesma forma que enfeita a si mesma com brilhos porque gosta, o depoimento de Gabriela, vinte e cinco anos, estilista e estudante de Moda, confirma ao extremo a tendência de estetização no uso dos aparelhos celulares:

Eu uso [o celular] mais pra estética mesmo. [O marido intervém]:

Pra ela [o celular] não precisa nem fazer ligação! [Gabriela, rindo]: É verdade, é verdade! Essa semana, essa semana por exemplo, eu pensei que eu tinha perdido o meu carregador. Mas agora eu achei ele dentro da gaveta. Então, eu tava com o celular desligado, mas eu mesmo assim usava a capinha, deixei ele na capinha com a bolsa e tudo, eu não tirei ele da capinha. E tava desligado, não tinha bateria, não tinha nada, até hoje. Mas hoje eu também saí com a bolsa, com o negocinho, capinha...

À tendência de estetização dos telefones celulares - que passam, como dissemos, a ser acessórios de moda - soma-se o ciclo de vida cada vez mais curto dos aparelhos. Entre nossos informantes de camadas médias, o tempo médio de troca de aparelhos celulares é de apenas um ano. Paula, que "não fica com o celular mais do que um ano" conta que "Às vezes a funcionalidade não é nem aquela toda que você espera, às vezes você compra pela aparência". Natasha, vinte e um anos, estudante universitária, conta que tem celular desde os treze anos de idade:

Foi assim, eu tava na oitava série, eu devia ter... treze anos. Treze pra catorze anos. Quando eu comprei... eu ganhei o meu primeiro celular dos meus pais, era um tijolão da Tim, e eu troco de celular todo ano. [Tu troca todo ano?!] Todo ano. Agora que eu dei uma parada. Mas celular... Era um vício mesmo, era como se fala, mais questão de moda. Eu já tive celular da Vivo, já tive da Tim, agora da Brasil Telecom, já tive da Claro, de todas as operadoras eu já tive celular. 
Entretanto, não são apenas os adolescentes brasileiros que têm o hábito de trocar aparelhos praticamente novos pelos últimos lançamentos, apensar de a funcionalidade destes ser bastante semelhante. Pesquisas de mercado recentes (MING, 2006) mostram que o tempo médio de troca de aparelhos celulares pelo consumidor brasileiro é de dois anos, caindo para um ano e meio entre as classes A e B. A razão disto, segundo especialistas da área, são principalmente duas: para o brasileiro, o celular é um item de moda que diz muito sobre o indivíduo e, portanto, o consumidor brasileiro tem a tendência de comprar celulares novos para exibi-lo para outros indivíduos ${ }^{8}$. Existe até uma comunidade virtual no site de relacionamentos Orkut, chamada "Eu adoro trocar de celular", que possui mais de oitocentos membros (MING, 2006). Esses dados empíricos parecem confirmar a atualidade dos insights de Simmel, que escreveu em 1904: "quanto mais nervosa é uma época, tanto mais rapidamente mudam suas modas". Igualmente, destaca Simmel a subordinação ao econômico que caracteriza a moda na modernidade, em oposição à sua origem mais pessoal: não aparece do nada uma nova moda. Ao contrário, "se produzem, desde cedo, artigos com a intenção de que sejam moda [...] a tal ponto que existem inventores e indústrias que trabalham exclusivamente para atender esse fim." (SIMMEL, 2002; p. 364, tradução da autora).

Trocar de celular com freqüência é uma prática que se confirma na análise das várias comunidades virtuais do site de relacionamentos Orkut. Da mesma forma, o reconhecimento do celular como um acessório de moda relevante para a apresentação dos indivíduos. Penso ser importante apontar, nesse registro, a construção que a publicidade faz do celular como um acessório de moda. A retórica dos anúncios publicitários de celulares como o modelo LG Prada, por exemplo, é a mesma dos anúncios de moda ligados à indústria do vestuário: pouco ou nenhum texto, modelos jovens e bonitos que demonstram "atitude" e "estilo". Nesse sentido, os nomes das comunidades, bem como os textos de apresentação, são bastante sugestivos: “Celular virou uma moda"; Comprador compulsivo de celular" ("Essa comunidade foi criada para você que tem uma compulsividade em comprar celular...

\footnotetext{
${ }^{8}$ Meus primeiros dados de campo parecem apontar em direção a tendência de que existem percepçōes acerca de que tipo de celular devem ter membros de determinada classe social. Eu mesma, por ter o mesmo celular em uso há mais de seis anos, já ouvi de amigos comentários do tipo "você não tem vergonha de atender esse celular em público?" Por outro lado, uma amiga, assistente social aqui em Florianópolis, já ouviu o mesmo comentário vindo de uma pessoa moradora da comunidade na qual trabalha. Por outro lado, recentemente causou espanto entre os assistentes sociais que trabalham na mesma comunidade o seguinte fato: uma moradora, queixando-se de que seu barraco estava caindo e de que algo precisava ser feito, mostrou aos profissionais uma foto no seu celular desse mesmo barraco.
} 
Se você é daqueles que quando ver (sic) um celular já pensa em comprá-lo, esta é a sua comunidade!"); "Troco de celular toda hora"; "Meu celular é da moda"; e "Meu celular é a minha cara", cujo texto de apresentação parece corroborar a afirmação de Lasen $(2004$, p. 1$)$ de que "a ligação emocional pode ser observada na personalização dos aparelhos":

\begin{abstract}
Para você que adora "fofoletizar" o seu cel!! Seja com capinhas coloridas de pelúcia, piercings, protetores de tela, papel de parede e tokes (sic) diferentes!!! Afinal o celular é SEU e ele tem que ter a SUA cara!!! E danese que os outros digam que infantil ou coisa de Patricinha!!!
\end{abstract}

No Orkut, existem várias comunidades de pessoas dedicadas a discutir essa nova prática de adornar os celulares, como por exemplo a "Eu adoro chaveiro de celular" e a "Meu celular tem estilo", cujo texto de apresentação diz: "Pingentes, capinhas descoladas, chaveiros de ursinhos, protetor de tela, figuras, fotos, adesivos, sons personalizados e etc., seu celular é bem desse estilo?! Você adora atualizar ele?! Então você tem que participar dessa comunidade..." Também existem comunidades muito populares, como a "Meu celular é enfeitado", que tem mais de mil membros. Gabriela, em seu depoimento, conta que muitas pessoas gostam de "colocar um tipo de toque diferente pra cada pessoa". Esses sons personalizados, ou ringtones, costumam refletir a personalidade desses indivíduos ou os sentimentos do proprietário do celular em relação a eles. Gabriela dá um exemplo: "[algumas mulheres] colocam o toque do marido a entrada do plantão da Globo...". Ao atuarem ativamente na modificação do aspecto original de seus celulares, os usuários parecem utilizá-los para criarem noções de si e dos outros. Nesse sentido, tanto quanto os imaginários divulgados na Internet e nas imagens publicitárias, os usuários de celulares atuam como co-criadores de seus significados públicos (KATZ \& SUGYIAMA, 2002).

Os motivos apontados para trocar de celular com freqüência estão ligados ao lançamento de novas funções, como tocador de músicas em MP3 e câmeras digitais cada vez mais potentes. Além destes, são apontadas razões ligadas ao status e à moda: "Porque é assim uma questão de status, pra mostrar que a pessoa tá melhor, tá na moda..."(Cláudia, assistente social, 


\section{HüMANAS}

membro das camadas médias). "Status, tá na moda, entendeu como é que é... tá no tempo... tá legal" (Marisa, faixa etária de trinta a quarenta anos, do lar e moradora de uma comunidade carente de Florianópolis).

Nesse registro, é preciso levar em conta o papel da publicidade na construção dos imaginários ligados ao telefone celular. Entendemos, apoiados em Katz e Sugiyama (2002) que a publicidade constitui uma das principais formas de construção do significado público dos telefones celulares. O comentário de Marcos, estudante universitário, membro das camadas médias, é bem ilustrativo a esse respeito:

Eu acho o seguinte. Vai muito da questão da mídia. Você hoje tem um celular como esse aqui, daqui um ano ele já não funciona mais do jeito que tu quer ou então, a mídia já... A tecnologia já ta tão avançada que o que tu tem já não é mais agradável pra ti e tu vai procurar um outro celular. Se a pessoa hoje tem condições de trocar um celular, todo ano, é que nem carro. Se tem condições de trocar o carro todo ano troca, entende? A tecnologia ta aí pra isso, então não vejo problema nenhum. Se eu puder trocar a cada ano o meu celular, eu vou trocar.

Os informantes, de uma forma geral, foram unânimes em afirmar que quem possui telefones celulares "é moderno, está no tempo, está no mundo" e que não possuí-lo, ou possuir um modelo mais antigo (referido como "tijolão" e, mais raramente, "patacão") implica em "vergonha" ou inferioridade social, diminuindo sua possibilidade de interação nas redes sociais. Simmel, em sua filosofia da moda, aponta para a relação entre moda e vergonha, ressaltando que são objeto desta aqueles agentes sociais que não estão no mesmo tom dos demais. Para Simmel, é a moda que permite que uma pessoa se destaque de uma maneira adequada. Em suas palavras, "a manifestação mais extravagante, se está na moda, livra o indivíduo do penoso reflexo que freqüentemente o acomete quando se sente objeto da atenção dos demais" (2002 [1904], p.379).

No Orkut, a comunidade "Tá com vergonha do meu celular?" acolhe os comentários daqueles cujos amigos "têm vergonha do seu celular"; que possuem "o famoso 'tijolo', considerado por muitos uma arma branca"; e, 
finalmente, cujo celular "já foi tema preferido de piadas e brincadeirinhas infames." Gabriela afirma que, antes de trocar seu celular antigo por um modelo mais novo, deixava-o tocando na bolsa e não o atendia para não "passar vergonha" em locais públicos. Nesse sentido, Marisa relata sua experiência:

Todo mundo repara. Porque eu fui no casamento do meu primo, e o celular do meu marido era um Nokia. Mas não era de abrir, de flip. Gente, quando o pessoal abriu o celular na mesa, eu [para o marido]: Carlos, desliga teu celular, desliga. Bota debaixo da mesa, não tira (...) todo mundo olhou, tomou um choque no celular dele.

Paula concorda que existe uma espécie de "cobrança" por parte das pessoas em relação aos que não aderem à lógica da troca constante do celular:

Existe. Existe, eu acho que hoje em dia as pessoas são caracterizadas não pelo que elas são, mas pelo que elas tem. Eu acho que, hoje em dia, a forma como você se veste conta muito, acaba a sociedade consumista tendo essa cobrança sobre nós como consumidores nessa sociedade e eu acho que o celular diz muito a respeito disso, né. Realmente eu tenho uma prima que tem um celular há muito tempo e as pessoas hoje em dia, "poxa, mas tu tá com ele há tanto tempo, não vais trocar, hoje em dia é tão barato, porque tu não troca?"

Neste ponto é importante evocar Simmel (2002 [1904]) e sua teoria filosófico-cultural sobre a moda para analisar os agentes sociais que aparentemente optam por não seguir a moda. Dois pontos da teoria simmeliana transparecem no depoimento acima: em primeiro lugar, a expressão da moda como elo de coesão social e, portanto, a "cobrança" a que se refere Paula para incluir no grupo aqueles que deste parecem destoar. Em segundo lugar, o fenômeno que Simmel chamou de "antimoda". Para Simmel, a moda éantes de mais nada um fenômeno de caráter social. Mesmo aqueles que a ela parecem opor-se, ou seja, os adeptos do que Simmel chamou de uma "antimoda", 


\section{HUMANAS}

dão testemunho de obediência d̀ ela tanto quanto aqueles que a seguem cegamente. Na visão de Simmel, a negação do exemplo social indica igualmente a força do poder exercido pela tendência social - ainda que, paradoxalmente, com signo inverso, pois a moda "de forma positiva ou negativa, nos faz seus súditos. A antimoda preconcebida se comporta diante das coisas da mesma forma que o adepto da moda, apenas regendo-se por outra categoria: enquanto este exagera cada elemento, aquela o nega" (2002 [1904], p. 374).

Passando a outro registro, posse de aparelhos celulares por crianças cada vez mais novas também esteve presente nos depoimentos dos informantes. Gabriela, estilista de roupas infantis, conta que as peças de malha com estampas de telefones celulares são bastante procuradas. Esse parece ser um exemplo de como o celular já parece ter se consolidado como elemento importante do imaginário associado à tecnologia, tanto para adultos quanto para crianças. Se para os primeiros a posse do celular traz novas possibilidades de inclusão simbólica em uma lógica de modernidade marcada pela conectividade e pela instantaneidade, assim como novas possibilidades de apresentação do eu, no caso das crianças soma-se a essas duas instâncias a posse do celular como uma espécie de ritual de passagem para a vida adulta. Natasha, estudante de vinte e um anos, que tem um irmão de nove anos que já possui celular, pensa que crianças que tem o aparelho devem "entender" a situação:

Eu não concordei muito no início, assim, de ele ter celular tão cedo, porque eu acho que tem que ter mais idade, até pra entender, pra não virar modismo. Não ter celular só por ter. Tem que ter um motivo, algo... Não, e esse é o celular novo. Que ele já tinha outro.

Vânia, empregada doméstica, quarta série primária, faixa etária de trinta a quarenta anos e moradora da mesma comunidade que Marisa, conta como seus filhos, de nove anos e onze anos de idade, às vezes pedem o celular emprestado quando sai com os amigos. Vânia possui dois celulares usados (um ganho de uma antiga patroa, outro do marido) e conta que os filhos preferem o modelo mais atualizado: "Esse aqui eles não pedem, dizem que é feio." Insisto no porquê: "É mesmo? Não querem nem saber? Nem emprestando assim não querem levar?" Vânia confirma: "Dizem assim ui mãe, que coisa feia. Isso aqui nem se usa mais, mãe." 


\section{O consumo no contexto da experiência urbana: reflexões sobre os telefones celulares}

Sandra Rúbia da Silva

\section{Considerações finais}

Como vimos, aquilo a que Simmel referiu-se como "a brevidade e escassez dos contatos inter-humanos conferidos ao homem metropolitano, em comparação com o intercâmbio social na pequena cidade" $(1979$, p. 22) é potencializada através do uso crescente das novas tecnologias de comunicação e informação. Uma análise da dimensão simbólica do consumo de telefones celulares, expressa nas novas práticas sociais e culturais a eles associadas, dá conta das crescentes relações entre cultura e consumo na contemporaneidade. A posse e a fruição dos aparelhos insere os indivíduos simbolicamente em redes de sociabilidade que os conectam ao estilo de consumo tecnológico característico da modernidade.

É no contexto de uma sociedade de consumo globalizada que os celulares passaram de simples instrumentos de comunicação à acessórios de moda, já que, como afirmam Katz e Sugyiama (2002, p. 79) “a dimensão do estilo é enormemente importante na maneira como os telefones celulares são percebidos, tanto pelos usuários quanto pelo público em geral." Os celulares tornaram-se regidos pela lógica da moda e, nesse sentido, passaram a ser parte importante da apresentação e inserção dos indivíduos em suas redes sociais e, mais ainda, parte importante de uma concepção contemporânea de pessoa que é profundamente atravessada pela tecnologia.

Em conclusão, a leitura de clássicos como Simmel sempre é instigante e, especialmente neste caso, revela seu papel visionário e sua atualidade na comparação com autores que retrabalham temáticas semelhantes. revela-se a persistência de tantos insights simmelianos. Exatamente como anteviu Simmel, são gêneses de mudanças espaço-temporais que afetaram e afetam profundamente, remodelam e inovam a dinâmica social.

\section{Referências bibligráficas}

BELL, G Talking notes: a cultural reading of mobile technologies. Artigo apresentado no MobiSys 2004 - The Second International Conference on Mobile Systems, Applications, and Services, 2004. Resumo disponível em: <www.intelresearch.net/ViewSeminarAbstract.asp?Index=153>.Acesso em: 20 set. 2005.

CAMPBELL, C. A ética romântica e o espírito do consumismo moderno. Rio de Janeiro: Rocco, 2001. 
KATZ, J. E.e SUGIYAMA, S. Mobile phones as fashion statements: the cocreation of mobile communication's public meaning. In: KATZ, James E.(org.). Perpetual contact: mobile communication, private talk, public performance. Cambridge: Cambridge University Press, 2002.

McCRACKEN, G. Cultura e consumo: novas abordagens ao caráter simbólico dos bens e das atividades de consumo. Rio de Janeiro: MAUAD, 2003.

MILLER, D e HORST, H. From Kinship to Link-up: cell phones and social networking in Jamaica. Current Anthropology, vol. 46, nr. 5, December 2005.

MING, L. Viva a alta rotatividade. Revista Veja, 26 de abril de 2006.

NASCIMENTO, F. S. Os últimos serão dos primeiros: uma análise sociológica do uso do telefone celular. 2004. 133f. Dissertação (Mestrado em Sociologia) - Universidade Federal do Ceará, Fortaleza, 2004.

SAHLINS, M. Cultura e razão prática. Rio de Janeiro: Jorge Zahar Ed., 2003.

SIMMEL, G. A metrópole e a vida mental. IN: VELHO, Otávio G. O fenômeno urbano. Rio de Janeiro: Jorge Zahar Eds., 1979.

SIMMEL, G. Filosofia de la moda. In: Sobre la individualidad y las formas sociales.Quilmes: Universidad Nacional de Quilmes, 2002. 